\title{
LAMPONGSCHE RAADSELS, SPREEKWOORDEN EN SPREEKWIJZEN
}

\author{
MEDEGRDEELD DOOR
}

0. L. HELF R I C H, Controleur bij het Binnenlandsch Bestuur.

\section{RAADSELS (TATẼDOEHAN.)}

1 Mĕsigit 'ari roewa pandaj kamboer, kaboenji kĕsamawas.

(Een) bedehuis (op) twee stijlen, (dat) vliegen kan, (en) tegen den morgen geluid geeft.

Oplossing: manoek (hoen).

2 Badanni saj 'iroengni wat sĕratoes.

Het heeft één lichaam en honderd neuzen.

(Letterlijk: zijn lichaam (is) één, zijn neus is honderd)

Oplossing: njanjas (de ananas).

$3 \mathrm{Ki}$ mĕugan 'ija mĕtoh, kok mak mĕngan 'ija mĕtong.

Indien (hij) eet, heeft hij honger, indien hij niet eet, is hij verzadigd.

Oplossing: Djala (werpnet).

4. Kapoedak mak ka'oeloe.

(Het) heeft 'n aangezicht, (doch) geen hoofd.

Oplossing: Bantal (kussen).

5 Bakakni di 'atas, boeloengni di bah.

Zijn wortel (is) boven zijn blad (is) beneden.

Oplossing: Tabir (gordijn, voorhangsel).

6 Kĕbawni taro, talini midor; of kĕlokni midor, kĕbawni mangkoek.

De karbouw houdt op, het (letterlijk: zijn) touw gaat; of het (letterlijk : zijn) touw gaat, de (letterlijk : zijn) karbouw houdt stil. Oplossing: 'Oebi; taw (meelachtige knollen (kruipplant); kalebas).

7 'Oedjan satoempok.

Een hoop regen. 
Oplossing: hoewok (zemelen, die bij het wannen van de wan neervallen).

8 Maloentjat tinggal mani.

(Wanneer het) springt, blijft zijn tong achter.

Oplossing: Kĕloepikni niboeng (hulsel van de niboeng).

9 Di tjoelik bangik, di kanik sakik.

Wordt (het) even met de vingers aangeraakt, (dan ruikt het) lekker, wordt (het) gegeten, (dan is het) pijnlijk.

Oplossing: Tjabi (lombok).

10 Di tjoelik sakik, di kanik bangik.

Wordt (het) even met de vingers aangeraakt, (dan is het) pijnlijk, wordt (het) gegeten, (dan is het) smakelijk.

Oplossing: Dĕrijan (de doerian).

11 Di 'imbaw boesoek, di kanik bangik.

Het heeft een' onaangenamen reuk (letterlijk wordt (er aan) geroken), (dan) stinkt (het), wordt (het) gegeten, (dan is het) smakelijk. Oplossing: Poekasom (bedorven visch die eene zekere bereiding ondergaat en als toespijs bij de rijst wordt genuttigd).

12 Di 'imbaw maroem, di kanik pahik.

Het heeft een aangenamen geur (letterlijk wordt (er aan) geroken), (dan is het) geurig, wordt (het) gegeten, (dan is het) bitter. Oplossing: Limoes poelan (eene wilde manggasoort wier vruchten aangenaam ruiken, doch oneetbaar zijn).

13 Kadjanggoek kandjak sanak, boekawaj kandjak rĕnik.

Het heeft een baard van kindsbeen af (letterlijk sinds een kind), (het heeft) een baadje aan (draagt een baadje) van zijne jeugd af (letterlijk sinds (het) klein (is)).

Oplossing: Djagoeng (mais).

14. Mĕsigit 'ari roewa, hatok sĕgĕloempajan.

(Een) bedehuis (op) twee stijlen, (een) dak van gespleten bamboe. Oplossing: Manoek (hoen).

15 Mĕna nganak djak ngandoeng.

(Het) bevalt eerder (het krijgt eerder kinderen) dan zwanger te zijn.

Oplossing: Pari (rijstplant).

16 Mini masak, rajohni pĕtjoh.

De (letterlijk : zijn) rijst (is) gaar, de (letterlijk : zijn) aarden pot valt uit elkander (breekt).

Oplossing: Dadoeroek (naam van een heester, Mal. Sikadoedoek). N.B. Als de vrucht van de Sikadoedoek rijp is, berst zij open. 
17 Wahni balag, batangni balag, boeloengni rĕpa pajoeng.

Zijn vrucht (is) groot, zijn stam (is) hoog, zijn blad gelijkt (letterlijk : gelijk aan) een scherm.

Oplossing: Gĕdang (de Pĕpaja).

18 Kaboenji mawat tjawa, makětjal mak katjoekoet.

(Het) geeft geluid, (doch) zegt niets; (het) gaat snel (letterlijk: siel van gang), doch heeft geen voeten.

Oplossing: Batang'ari (rivier).

19 Mĕngan rang těnaj, mising rang toendoen.

(Het) eet bij den buik (letterlijk: wáar buik), (het) doet zijn gevoeg bij den rug (letterlijk: wár rug).

Oplossing: Kĕtam (schaaf).

20 Kambang roem dilom padang ma'asar, tĕraj kindo koetjoem, kĕmarau kindo mĕkar.

(Een) geurige bloem op de maäsar-vlakte, (als het) regent (dan) sluit (het) zich, (als het) droog weêr is, (dan) ontluikt (het). Oplossing: Matarani (matanirani) (de zon).

21 Dibah kaboeloe, di'atas kaboeloe; kok 'ija pětangkoep, ngaloepakon dĕnija.

Van beneden (is het) behaard, van boven (is het) behaard; als het tegen elkander sluit, (dan) doet (het) de wereld vergeten.

Oplossing: Mata (het oog).

22 Boeloengni saj, matani wat sĕriboe.

Het heeft één blad en duizend oogen.

(Letterlijk: zijn blad (is) een, zijn oog is duizend).

Oplossing: Djala (een werpnet).

23 Mas ti'oenjoek, sĕlaka di tĕpa nipis, bintan dawah, 'imboen tĕgi rani.

Goud (dat) getrokken is, zilver (dat) plat gesmeed wordt, 'n ster (bij) daglicht, 'n nevel midden op den dag.

Oplossing: Roekoek (sigaar).

24. Hoerik mak didok njawa, kaboenji mak běbangoek, maroewa bĕlas tjawa dilom rani kĕbijan.

(Het) leeft (maar) heeft geene ziel, (het) geeft geluid (maar) heeft geen mond, twaalf malen spreekt (het) op één dag.

Oplossing: Djam (klok).

25 Badanni saj, tjoekoetni wat sĕriboe.

Het heeft één lichaam en duizend pooten.

Oplossing: Haloepan (duizendpoot). 


\section{SPREEKWOORDEN EN SPREEKWIJZEN. (SEัSIKOEN).}

1 Noewar lĕmasa, nanom kĕmoerakni.

Den tjĕmpědak vellen, zijn pit planten.

V.g.l. Mal.: mĕninggalkan poentoeng, mĕngĕdjar 'asap.

Ons: Een ouden schoen wegwerpen, vóór men een nieuwen heeft.

2 Patik loetjoek, djalang mak dapok.

(Men) laat den vechthaan los, (den) boschhaan vangt men niet.

V.g.l. Mal.: lěbih ba'ik sabĕloemboeng padi dĕngan sěnang 'ati dari pada sětĕngkijang padi dĕngan soesah 'ati.

Ons: beter één vogel in de hand dan tien in de lucht.

3 Manoek loetjoek, manangni tinggal.

(Indien) de vogel wegvliegt (loetjoek beteekent letterlijk los, losgelaten, bevrijd), blijft zijn drek achter.

V.g.l. Mal.: mati gadjah tinggal gadingnja.

$$
\begin{array}{lll}
\text { " harimaw " koelitnja. } & \text {, } \\
\text { " } & \text { namanja. }
\end{array}
$$

4. Saboek moerak, tinggal kĕmasini lagi.

- (Indien) het vezelachtig omhulsel van den arèn vergaan (is), blijven nog zijne stekels achter.

Heeft dezelfde beteekenis als no. 3 .

5 Ki Kĕbaw, koeroek di sangkak Kĕbaw;

" Kambing, " " " Kambing;

"Manoek, " " " Manoek;

Een karbouw gaat binnen in eene karbouwenkraal.

" geit, " " een geitenhok.

" kip " " " een kippenhok.

V.g.l. Mal. : ranting 'orang di patah 'ajĕr 'orang di sa'oek, adat orang di toeroet.

Ons: 's Lands wijs, 's lands eer.

6 Ngětokkon toengoeni 'oeloen, toengoe ram mak tĕ rasaj.

De toengoe (naam van een insect dat zich in het lichaam en 
de huid van dieren vastzet) van iemand anders wegwerpen, één toengoe van ons wordt niet gevoeld.

V.g.l Mal.: toengaw di sěběrang lawot kĕlihatan gadjah bětinggir di pĕloedak mata, tidak kalihatan.

Ons: den splinter zién in het oog van onzen naaste, den balk in eigen oog niet.

7 Mĕrabaj di 'antoe, njoempik majat.

Bevreesd zijn voor den geest, het lijk omhelzen.

V.g.l. Mal. : takoet di 'antoe, těpěloek di majit.

8 Pantang mak nganik tor, boelalĕdjoe di goela; rabaj kĕna roewi, koeroek di poelan toeha.

(Het is) verboden (géén) zoetigheid te eten, toch verzadigd worden van suiker; bevreesd om door doorns geraakt te worden, (toch) het oerwoud ingaan.

V.g.l. Mal.: patah sĕliro banjak makan.

9 Saj tihadjat soemang tigoewaj; saj ti'antjam tilingoeki.

Wat voorgenomen wordt (wordt niet ten uitvoer gebracht, doch) iets anders verricht; dien men op het oog heeft, wordt de rug toegekeerd.

V.g.l. Mal.: poekoel 'anak sĕnding mĕnantoe.

10 Lijak di boeng,

mak harap di sĕnawi;

rabaj di tětos boeloeng,

sansat mĕrkak roewi.

Zien naar het eetbaar uitspruitsel van de bamboes, niet hopen

op den bladerloozen bamboesstoel; bevreesd om een blad op zijn hoofd te krijgen, er niet om geven zich met vaart op doornen te werpen.

V.g.l. Mal.: toewah koeda,

tjilaka 'andjing,

bidoek 'ada,

maka bĕrnang.

11 Nampar waj di djahas, nampok mata djama hĕni ngikokkan galah di kapar. 
Op water in een houten schaal slaan, zich in het aangezicht (letterlijk: het oog) met zand werpen, den hals vastleggen aan drijf hout.

V.g.l. Mal.: mĕnĕpoek 'ajĕr di doelang mĕloedah, kĕlangit mĕntjabik badjoe di dada, 'awak djoega jang kĕkĕnaj.

Ons: Zich in het angezicht slaan.

12 Ngoeta landos; ngapĕtĕgi djă di haroes; nimba lawok; njakak langit mak boedjan.

Een vlakte omheinen; een trap overeind zetten in den stroom; de zee uithoozen; in den hemel klimmen en geen trap hebben.

V.g.l. Mal. 'oepama si tjaboel handak mĕntjapaj boelan, mĕnimba lawoet tangan sěbĕlah.

Ons: Zout naar de zee dragen (vergeefsch werk doen).

13 'Imboen mĕndjadi hoemara; kajoe bĕringin mampangkon mas; matanirani roewa; waj ngoenggah poematang.

De nevel wordt eene monding van eene rivier; de baringin schiet takken van goud; twee zonnen; het water stroomt naar den berg.

V.g.l. Mal.: mĕnghĕndakkan dadi 'oenta djalang.

14. Loepoet di mata lěbon di (h) 'ati.

V.g.l. Mal.: djawoh di mata, djawoh di hati.

Ons : Uit het oog, uit het hart.

15 Bĕtik di poedak, boerak di (h)'ati.

V.g.l. Mal.: manis moekaw, boesoek di hati.

Ons: Een huichelaar.

16 'Adoe těsĕroep ampaj njalok rawong.

Reeds (is men) met den voet in een gat gevallen, (dan) érst het gat dichtmaken.

V.g.l. Mal.: lah kĕnaj maka 'ingat.

Ons: Als het kalf verdronken is, dempt men den put.

17 Ki lĕmawong radoe kaboenji mawat nganik djĕlma.

Indien een tijger reeds geluid geeft, (dan) eet (hij) geen mensch op. V.g.l. Mal.: 'andjing jang mĕnjalak tidak mĕnggigit.

Ons: Blaffende honden bijten niet. 
18 Batoe toembak di 'oelok.

Een steen (die) in een diepe plaats in eene rivier valt.

V.g.l. Mal.: 'mbak koetjing toeroen sĕndjo.

Ons: Het is paarlen voor de zwijnen werpen.

19 Dang 'oendakkan boesoekni 'oeloen.

Haal het vuil van een ander niet te voorschijn.

V.g.l. Mal ; djangan mĕmbongkar pěkasam lama.

Ons: Haal geen oude koeien uit de sloot.

20 Dang di kitjik boesoekni 'oeloen,

boesoek-moe mak di kĕpandaj'i.

Spreek niet over de smerigheid van een ander, uwe (eigen) smerig-

heid is $(\mathrm{u})$ niet bekend (letterlijk wordt door u niet geweten). V.g.l. no. 6.

21 Loepa rĕtak di bawakni.

De boon is haar schil vergeten.

V.g.l. Mal.: Loepa kátjang di koelitnja.

Ons: Als niet komt tot iet, dan kent iet zich zelven niet.

22 Ki lĕmawoeng risok kělijak'an, kambing 'adoe rĕngam.

Indien de tijger vaak gezien wordt, dan (komen) de geiten (in) moeilijkheid.

V.g.l. Mal.: takoet orang di harimaw kĕrna bĕlangnja, takoet di gadjah kĕrna gadingnja

Het komt wel wat overeen met ons: met groote heeren is het slecht kersen eten.

23 Mawat mĕndjawoh boeng djiak roempoenni.

Het eetbare uitspruitsel van het bamboesriet is niet ver van den stoel V.g.l. Mal.: Rĕboeng tidak djahoe dari roempoennja.

Ons: De appel valt niet ver van den boom.

24. Mak kajoe mampangkon perring.

(Er is) geen houtsoort (die) takken (van) bamboes schiet.

V.g.l. Mal.: koerik bapaknja, rintik 'anaknja.

Ons: Zooals de ouden zingen (of: piepen) de jongen.

25 Sĕtahoen katji těkoegroeng; ki těkas nganik tahi djoega. 
Een jaar wordt een hond opgesloten : indien (hij) ontsnapt, eet (hij) toch uitwerpselen.

V.g.l. Mal.: 'Acal 'itik hĕndak kapělambahan, 'acal ajam hĕndak kalĕsoeng.

Ons: De natuur verloochent zich niet; komt ook wel overeen met ons : De vos verliest wel zijne haren, doch niet zijn streken,

26 Di waj di kanik boeha, di darak di kanik lěmawoeng.

In het water wordt (men) door een krokodil opgegeten, op het land wordt (men) door een tijger opgegeten.

V.g.l. Mal.: kahilir kĕna loekah, kamoedik kĕna těngkalak.

27 Mĕmbatok sĕrok di Tjina

Naalden brengen naar China.

V.g.l. Mal.: mĕmbawa garam kala'oet.

V.g.l. $\mathrm{n}_{0} .12$.

28 Djagoek nganakkon manoek baroega.

Een hoen die een boschhaan ter wereld brengt.

V.g.l. Mal.: Kambing mĕnganakkan harimaw.

29 Sadjawoh-djawohni 'iwa midor, moelang di boemboenni djoega. Hoe ver een visch ook gaat, (hij) keert toch naar de boemboen (rond gat midden in de sawah waar op kunstmatige wijze vischteelt plaats heeft) terug.

V.g.l. Mal.: Satinggi-tinggi tĕrbang bangaw soeroetnja kakoebangan djoega. 